\title{
Moderasi Good Corporate Governance Terhadap Pengaruh Risiko Perusahaan Pada Manajemen Laba
}

\author{
Ida Ayu Devi Candra Pradnyani ${ }^{1}$ \\ Ida Bagus Putra Astika ${ }^{2}$ \\ ${ }^{1,2}$ Fakultas Ekonomi dan Bisnis Universitas Udayana (Unud), Bali, Indonesia \\ e-mail: devicandra88@gmail.com
}

\begin{abstract}
ABSTRAK
Risiko perusahaan adalah suatu kondisi dimana kemungkinan-kemungkinan yang menyebabkan kinerja suatu perusahaaan menjadi lebih rendah dari pada apa yang diharapkan perusahaan karena adanya suatu kondisi tertentu yang tidak pasti di masa mendatang. Di penelitian ini risiko perusahaan diproksikan dengan leverage. Leverage adalah rasio penggunaan hutang oleh perusahaan yang digunakan sebagai pendanaan untuk pengeluaran perusahaan. Penelitian ini mengambil sampel berdasarkan metode non probability sampling dengan teknik purposive sampling pada perusahaan manufaktur di Bursa Efek Indonesia pada rentang tahun 2014-2016. Jumlah sampel yang diperoleh yaitu 204 observasian. Dalam penelitian ini teknik analisis data yang digunakan yaitu uji regresi sederhana dan uji Moderated Regression Analysis (MRA). Berdasarkan hasil analisis penelitian ini ditemukan bahwa risiko perusahaan berpengaruh positif pada manajemen laba. GCG mampu dalam memoderasi pengaruh risiko perusahaan pada manajemen laba.

Kata Kunci: Manajemen laba, risiko perusahaan, leverage, GCG, komite audit.
\end{abstract}

\section{ABSTRACT}

The risk of a company is a condition for the possibilities that cause a firm's performance to be lower than what the company expects because of a certain uncertain condition in the future, and the risk of the company is proxied by leverage. Leverage is the ratio of debt usage by firms used as funding for corporate expenses. This study took a sample based on non-probability sampling method with purposive sampling technique at manufacturing companies in Indonesia Stock Exchange in the range of 2014-2016. The number of samples obtained is 204 observations. The data analysis technique used is simple regression test and Moderated Regression Analysis (MRA) test. Based on the results of this research analysis found that corporate risk has a positive effect on earnings management. GCG is able to moderate the effect of corporate risk on earnings management.

Keywords: Earnings management, corporate risk, leverage, GCG, audit committee.

\section{PENDAHULUAN}

Secara umum laporan keuangan terdiri dari laporan posisi keuangan, laporan laba rugi, dan laporan ekuitas dan laporan arus kas yang disusun berdasarkan basis akrual. Informasi laba yang merupakan bagian dari laporan keuangan sering menjadi target rekayasa manajemen untuk memaksimumkan kepentingan 
Ida Ayu Devi Candra Pradnyani dan Ida Bagus Putra Astika. Moderasi...

pribadinya. Tindakan oportunitis tersebut dilakukan dengan cara memilih metode akuntansi tertentu, sehingga laba perusahaan dapat diatur (dinaikkan maupun diturunkan) sesuai keinginannya atau motif yang mendasarinya. Apakah motif bonus, motif hutang ataukah motif kontrak politis (Watt and Zimmerman, 1986). Bagi para investor laba yang dicapai merupakan indikatoryang digunakan untuk mengukur kinerja operasional perusahaan. Kegagalan dan keberhasilan dalam bisnis dapat dilihat dari informasi laba yang ada (Siallaganidani Machfoeds, 2006).Oleh karena itu, manajemen melakukan tindakan yang dapat membuat laporan keuangan terlihat baik, salah satunya adalah melakukan manajemen laba.

Manajemen laba adalah suatu kondisi dimana manajemen melakukan intervensi dalam proses penyusunan laporan keuangan bagi pihak eksternal sehingga dapat meratakan, menaikkan, dan menurunkan laba (Schipper, 1989). Healy dan Wahlen (1999) menyatakan bahwa manajemen laba terjadi ketika manajemen menggunakan keputusan tertentu dalam pelaporan keuangan dan penyusunan transaksi-transaksi yang mengubah laporan keuangan. Tindakan tersebut memiliki tujuan untuk menyesatkan para pemangku kepentingan (stakeholders) tentang kondisi kinerja ekonomi perusahaan. Disamping itu, tindakan tersebut mempengaruhi penghasilan kontraktual melalui pengendalian angka akuntansi yang dilaporkan. Manajemen laba adalah usaha manajemen untuk mempengaruhi laba yang dilaporkan dengan memberikan informasi mengenai keuntungan ekonomis (economic advantage) yang sesungguhnya tidak dialami perusahaan, dan dalam jangka panjang tindakan itu bisa merugikan perusahaan. 
Penelitian ini menempatkan risiko perusahaan sebagai variabel yang mendorong terjadinya manajemen laba. Usaha perusahaan untuk mencari sumber dana diluar modal sendiri merupakan bentuk risiko, karena perusahaan memiliki kewajiban untuk menyelesaikan atau membayarnya dikemudian hari. Pada penelitian ini risiko perusahaan diproksikan dengan leverage .Leverage mencerminkan besarnya hutang yang digunakan untuk pembiayaan oleh perusahaan dalam menjalankan aktivitas operasinya. Semakin besar penggunaan hutang maka semakin banyak juga kesempatan investasi yang dapat diraih perusahaan dengan risiko yaitu beban bunga yang juga ditanggung oleh perusahaan.Untuk menjaga kepercayaan bank maka dapat diduga melakukan manajemen laba dengan pola income increasing atau meningkatkan laba agar fasilitas kredit tidak diturunkan (Watt and Zimmerman, 1986). Hutang dapat mendorong perusahaan untuk melakukan manajemen laba saat perusahaan ingin mengurangi kemungkinan pelanggaran perjanjian hutang dan meningkatkan posisi tawar perusahaan selama negosiasi hutang (Klein, 2002 dan Othman dan Zhegal, 2006).

Perusahaan akan berusaha menghindari default dengan membuat kebijaksanaan yang dapat meningkatkan pendapatan maupun laba, dengan demikian akan memberikan posisi bargaining yang relatif lebih baik dalam negosiasi atau penjadwalan hutang-hutang perusahaan. Leverage yang tinggi juga akan meningkatkan perilaku oportunis manajemen seperti melakukan manajemen laba untuk mempertahankan kinerjanya di mata pemegang saham dan publik 
Ida Ayu Devi Candra Pradnyani dan Ida Bagus Putra Astika. Moderasi...

maka hal ini merupakan akibat dari kurangnya pengawasan. Leverage pada penelitian ini dihitung menggunakan debt of assets ratio (DAR).

Menurut Veno (2015) tindakan manajemen laba dapat ditekan melalui mekanisme good corporate governance (GCG). GCG merupakan sebuah konsep yang didasarkan pada teori keagenan, yang diharapkan dapat berfungsi sebagai suatu alat untuk memberikan keyakinan kepada para investor bahwa mereka akan menerima return atas dana yang telah mereka investasikan. GCG berkaitan dengan bagaimana para investor yakin bahwa manajer akan memberikan keuntungan bagi mereka, serta manajer tidak akan menggelapkan atau menginvestasikan ke dalam proyek - proyek yang tidak menguntungkan berkaitan dengan dana (capital) yang telah ditanamkan oleh investor.

Pada prinsipnya GCG terkait dengan kepentingan para pemegang saham, perlakuan yang sama terhadap para pemegang saham, peran semua pihak yang berkepentingan (stakeholders), transparansi dan kejelasan. Banyak perusahaan terutama yang berskala besar telah menaruh perhatian kepada pentinganya GCG. Menurut Forum of Corporate Governance (2011) menyatakan bahwa GCG adalah serangkaian proses, kebijakan, tata cara, institusi dan aturan yang mempengaruhi pengontrolan, pengarahan dan pengelolaan suatu perusahaan. GCG juga mencakup hubungan antara pemegang saham mayoritas dan minoritas, manajer, staff, kreditor, pemerintah, serta stakeholders yang memiliki kaitan terhadap hak dan tanggung jawab pada perusahaan atau sistem yang melakukan kendali dan arahan terhadap perusahaan. 
Secara konkret prinsip Corporate Governance memliliki beberapa tujuan yaitu memberikan kemudahan informasi mengenai akses investasi domestik maupun asing, mendapatkan cost of capital yang lebih murah, memberikan sebuah keputusan terhadap kinerja ekonomi perusahaan, dapat meningkatkan kepercayaan stakeholder terhadap perusahaan. Kinerja perusahaan dapat dipengaruhi oleh konflik-konflik yang muncul di dalam perusahaan itu sendiri, konflik tersebut muncul karena adanya suatu kepentingan yang berbeda antara agen dan principal. Jensen dan Meckling (1976) menyatakan bahwa konflik kepentingan tersebut dapat diminimumkan melalui mekanisme monitoring yang bertujuan untuk menyelaraskan berbagai kepentingan tersebut.

GCG memiliki dua konsep, yaitu: pemisahan antara kepemilikan dan pengendalian perusahaan. Pemisahan ini akan menimbulkan masalah karena adanya perbedaan kepentingan antara pemegang saham dengan pihak manajemen (Jensen dan Meckling, 1976). Tujuan utama dari GCG adalah minimalisasi biaya perusahaan (agency costs) yang berasal dari pemisahan kepemilikan dan pengendalian. Jika suatu perusahaan menerapkan GCG, maka potensi seorang manajer dalam melakukan tindakan manajemen laba dapat di kontrol. Menurut Herawaty (2008) teori keagenan memberikan pandangan bahwa masalah manajemen laba dapat diminimumkan dengan pengawasan sendiri melalui GCG.

Mekanisme penerapan GCG dapat digolongkan menjadi dua mekanisme yaitu mekanisme penerapan secara internal dan mekanisme penerapan secara eksternal (Fadhilah, 2014). Mekanisme penerapan GCG secara internal merupakan usaha yang dilakukan perusahaan untuk mengendalikan perusahaan 
Ida Ayu Devi Candra Pradnyani dan Ida Bagus Putra Astika. Moderasi...

dengan berdasarkan proses dan struktur internal seperti proporsi dewan komisaris, komposisi dewan direksi, rapat umum pemegang saham, pertemuan dengan board of director, dan proporsi dewan komisaris independen. Mekanisme penerapan GCG eksternal merupakan usaha pengawasan oleh perusahaan, pengendalian pasar, serta struktur kepemilikan.

Kepemilikan manajerial dapat ditingkatkan untuk mengurangi konflik keagenan. Kepemilikan manajemen terhadap saham perusahaan dipandang dapat menyelaraskan potensi perbedaan kepentingan antara pemegang saham luar dengan manajemen (Jensen dan Meckling, 1976). Kepemilikan manajerial yang tinggi akan membuat pemilik saham institusional akan mempunyai sedikit kesempatan kontrol pada perusahaan. Adanya kepemilikan institusional tentunya menyebabkan pengawasan atas perusahaan yang optimal karena investor institusional lebih aktif dalam mengawasi perusahaan. Investor institusional dapat mengawasi secara aktif karena pada investor institusional sendiri terdapat para profesional yang ditugaskan untuk mengawasi, selain itu investor institusional cenderung berinvestasi dalam jumlah yang besar sehingga pengawasan investor institusional tentunya lebih aktif (Wiranata dan Nugrahanti, 2013).

Penelitian yang dilakukan oleh Midiastuty dan Machfoedz (2003) juga menemukan bahwa adanya kepemilikan institusional yang tinggi membatasi manajer untuk melakukan pengelolaan laba (earnings management). Hasil penelitian Jiambalvo et al (dalam Herawati, 2008) menghasilkan nilai absolut diskresioner yang memiliki hubungan negatif dengan kepemilikan institusional. Dewan komisaris independen mempunyai tugas yaitu mensupervisi dan memberi 
nasehat kepada dewan direksi, dan memastikan bahwa perusahaan telah melaksanakan tanggung jawab kepada para stakeholder. Penelitian Midiastuty dan Mahfoedz (2003) dalam Sari dan Astika (2015) menyatakan bahwa perusahaan yang memiliki komposisi anggota dewan komisaris yang berasal dari luar perusahaan atau outside directur dapat mempengaruhi tindakan manajemen laba. Dewan komisaris independen sangat berperan penting dalam mengawasi kinerja manajemen. Dewan direksi membentuk komite audit untuk mengaudit operasi dan keadaan perusahaan.

Berdasarkan latar belakang yang dijabarkan, maka rumusan masalah penelitian ini meliputi 1) Apakah risiko perusahan berpengaruh pada manajemen laba? 2) Apakah GCG memoderasi pengaruh risiko perusahaan pada manajemen laba?

Agency theory merupakan konsep yang menjelaskan hubungan antara agent (manajemen) dan principal (investor). Pihak principal (investor) berperan sebagai penyedia sumber daya dan dana yang digunakan oleh manajemen. Pihak manajemen bertanggungjawab penuh dalam kegiatan pengolahan sumber daya dan dana tersebut agar dapat memenuhi kepentingan pihak principal. Pihak principal melakukan pengawasan atas kinerja pihak agen melalui laporan kinerja dan keuangan yang disampaikan oleh pihak manajemen. Setiap pihak memiliki hak dan tanggung jawab dalam pengelolaan dan setiap pihak harus mempunyai komitmen untuk menghargai dan menghormati hak dan wewenang pihak lain, serta tidak diperbolehkan untuk mengintervensi hak dan kewajiban pihak lain. 
Ida Ayu Devi Candra Pradnyani dan Ida Bagus Putra Astika. Moderasi...

Agency theory mengimplikasikan adanya asimetri informasi antara manajer (agent) dengan pemilik (principal). Asimetri informasi merupakan suatu keadaan dimana pihak agen (manajer) memiliki akses informasi yang lebih luas dibandingkan dengan pihak principal. Jensen dan Meckling (1976) berpendapat bahwa jika kedua kelompok (agent dan principal) tersebut adalah orang-orang yang berupaya memaksimalkan utilitasnya, maka terdapat alasan yang kuat untuk meyakini bahwa agen tidak akan selalu bertindak yang terbaik untuk kepentingan principal. Principal dapat membatasinya dengan menetapkan insentif yang tepat bagi agen dan melakukan monitor yang didesain untuk membatasi aktivitas agen yang menyimpang.

Terdapat tiga jenis konflik keagenan yang sering terjadi, yaitu: (1) Konflik antara pemegang saham dengan manajemen, (2) Konflik antara pemegang saham dengan pemegang hutang, dan (3) Konflik antara pemegang saham mayoritas dengan minoritas (Purwantini, 2011). Teori akuntansi positif (positive accounting theory) berupaya menjelaskan sebuah proses yang menggunakan kemampuan, pemahaman, dan pengetahuan akuntansi serta penggunaan kebijakan akuntansi yang paling sesuai untuk menghadapi kondisi tertentu dimasa mendatang. Perusahaan yang makin dekat terhadap pelanggaran pada akuntansi yang didasarkan pada kesepakatan utang, maka kecenderungannya adalah semakin besar kemungkinan manajer perusahaan memilih prosedur akuntansi dengan perubahan laba yang dilaporkan dari periode masa depan ke periode masa kini. Alasannya adalah laba yang dilaporkan yang makin meningkat akan menurunkan kelalaian teknis. Berdasarkan hipotesis kesepakatan hutang, ketika 
perusahaan mendekati kelalaian atau memang sudah berada dalam lalaiatau cacat, lebih cenderung untuk melakukan hal - hal yang dapat meningkatkan laba di laporan keuangan, salah satunya dengan melakukan manajemen laba (Sari dan Astika, 2015).

Scott (2006) menyatakan bahwa teori akuntansi positif adalah teori yang memprediksi tindakan pemilihan kebijakan akuntansi oleh manajer dan bagaimana manajer akan merespon kebijakan akuntansi baru yang diusulkan. Menurut Watts dan Zimmerman (1986) untuk mengurangi kesenjangan normatif, dikembangkan pendekatan positif yang lebih berorientasi pada penelitian empiris dan menjustifikasi berbagai teknik atau metode akuntansi yang sekarang digunakan atau mencari model baru untuk pengembangan teori akuntansi di kemudian hari.

Menurut Healy dan Wahlen (1999) menyatakan bahwa manajemen laba terjadi ketika manajer menggunakan penilaian dalam pelaporan keuangan dan penataan transaksi untuk mengubah laporan keuangan sehingga menyesatkan beberapa stakeholder tentang kinerja ekonomi perusahaan atau untuk mempengaruhi hasil kontrak yang bergantung pada angka akuntansi yang dilaporkan. Manajemen laba sering dianggap sebagai teknik yang digunakan oleh manajemen perusahaan secara sengaja mempengaruhi laba untuk disesuaikan dengan akhir yang diinginkan. Dengan kata lain, manajemen laba merupakan keputusan yang diambil oleh manajer dalam memilih kebijakan akuntansi tertentu yang dianggap bisa mencapai tujuan yang diinginkan, baik itu untuk meningkatkan laba atau mengurangi tingkat kerugian yang dilaporkan. 
Ida Ayu Devi Candra Pradnyani dan Ida Bagus Putra Astika. Moderasi...

Manajemen laba dapat dilakukan dengan mengambil keuntungan dari efek pilihan akuntansi yang memberikan dasar bagi keputusan yang terbaik bagi perusahaan (Noor et al. 2015). Salah satu upaya yang dilakukan manajer yaitu mengganti atau mengubah suatu metode akuntansi tertentu dari sekian banyak metode yang dapat dipilih, yang tersedia dan diakui oleh prinsip akuntansi yang berlaku umum (GAAP). Hal ini berarti bahwa perusahaan yang mempraktikkanmanajemen laba akan mengelola pendapatan mereka dalam batasbatas prosedur akuntansi yang berlaku (Rahman dan Ali, 2006). Manajemen laba merupakan salah satu faktor yang dapat mengurangi kredibilitas laporan keuangan, manajemen laba menambah bias dalam laporan keuangan dan dapat mengganggu pemakai laporan keuangan yang mempercayai angka laba hasil rekayasa tersebut sebagai angka laba tanpa rekayasa (Setiawati dan Na'im, 2000).

Di penelitian ini risiko perusahaan diproksikan dengan leverage.Leverage adalah rasio penggunaan hutang oleh perusahaan yang digunakan sebagai pendanaan untuk pengeluaran perusahaan dan rasio ini juga dapat digunakan untuk mengukur besarnya aktiva yang diperoleh perusahaan, yang pembiayaannya berasal dari penggunaan utang. Semakin besar penggunaan hutang oleh perusahaan, maka semakin banyak jumlah beban bunga yang diderita oleh perusahaan, sehingga dapat diduga melakukan manajemen laba karena perusahaan terancam default, yaitu tidak dapat memenuhi kewajiban membayar hutang pada waktunya.

Perusahaan yang memiliki utang tinggi akan memilih kebijakan akuntansi dengan menggeser laba masa depan ke masa sekarang. Pernyataan ini juga 
dibuktikan oleh penelitian Herawati dan Baridwan (2007) yang memberikan bukti empiris tentang adanya tingkat manajemen laba yang lebih besar pada perusahaan yang terikat perjanjian utang daripada perusahaan yang tidak terikat perjanjian hutang.Berdasarkan paparan teori serta penelitian terdahulu dapat disusun hipotesis sebagai jawaban sementara pada penelitian ini sebagai berikut:

$\mathrm{H}_{1}$ : Risiko perusahaan berpengaruh positif pada manajemen laba.

Menurut Forum for Corporate Governance in Indonesia (2011) GCG adalah seperangkat peraturan yang mengatur hubungan antara pemegang saham, pengurus (pengelola) perusahaan, pihak kreditur, pemerintah, karyawan serta para pemegang kepentingan intern dan ekstern lainnya yang berkaitan dengan hak hak dan kewajiban mereka atau dengan kata lain suatu sistem yang mengatur dan mengendalikan perusahaan.

Penerapan GCG di perusahaan diharapkan dapat mencegah upaya earning management (manajemen laba) karena adanya asas transparansi yang harus dipenuhi oleh perusahaan dalam melaporkan laporan keungan perusahaan. Komponen GCG yang digunakan dalam penelitian ini yaitu kepemilikan manajerial, kepemilikan institusional, proporsi komisaris independen, dan komite audit. GCGmerupakan suatu sistem yang mengatur dan mengendalikan perusahaan yang diharapkan dapat memberikan dan meningkatkan nilai perusahaan kepada pemegang saham. Dengan demikian, penerapan GCG dipercaya dapat meningkatkan nilai perusahaan. Praktek GCG antara lain meliputi keberadaan komisaris independen, kepemilikan manajerial, kepemilikan institusional dan kualitas audit. 
Ida Ayu Devi Candra Pradnyani dan Ida Bagus Putra Astika. Moderasi...

Menurut Yamaditya (2014) leverage mempunyai hubungan dengan praktik manajemen laba, ketika perusahaan mempunyai rasio leverage yang tinggi maka perusahaan cenderung akan melakukan praktik manajemen laba karena perusahaan terancam tidak bisa memenuhi kewajiban dengan membayar hutangnya tepat waktu. Semakin meningkat rasio leverage (dimana beban hutang juga semakin besar) maka hal tersebut berdampak terhadap profitablitas yang diperoleh perusahaan, karena sebagian digunakan untuk membayar bunga pinjaman. Penelitian yang dilakukan oleh Wibisana dan Ratnaningsih (2014), Yeni Januarsi dkk (2014) menyatakan bahwa leverage berpengaruh signifikan pada manajemen laba.

Penelitian yang dilakukan Wiranata dan Nugrahanti (2013) menyatakan bahwa dengan adanya kepemilikan institusional yaitu salah satu proksi GCG tentunya menyebabkan pengawasan atas perusahaan yang optimal karena investor institusional lebih aktif dalam mengawasi perusahaan. Investor institusional dapat mengawasi secara aktif karena pada investor institusional sendiri terdapat para profesional yang ditugaskan untuk mengawasi, selain itu investor institusional cenderung berinvestasi dalam jumlah yang besar sehingga pengawasan investor institusional tentunya lebih aktif. Hasil penelitian yang dilakukan Herawati (2009), Jao dan Pagulung (2011) menyatakan GCG berpengaruh positif pada manajemen laba.Berdasarkan paparan teori serta penelitian terdahulu dapat disusun hipotesis sebagai jawaban sementara pada penelitian ini sebagai berikut: $\mathrm{H}_{2}$ : GCG mampu memoderasi pengaruh risiko perusahaan pada manajemen laba. 


\section{METODE PENELITIAN}

Desain penelitian yang digunakan dalam penelitian ini adalah pendekatan kuantitatif yang berbentuk asosiatif. Sugiono (2014) menyatakan bahwa penelitian asosiatif adalah penelitian yang bertujuan untuk mengetahui hubungan dua variabel atau lebih. Dalam penelitian ini variabel yang diteliti meliputi tiga jenis variabel yaitu variabel bebas (independent), variabel terikat (dependent) dan variabel moderasi. Variabel terikat dalam penelitian ini adalah manajemen laba (Y). Variabel bebas dalam penelitian ini yaitu risiko perusahaan yang di proksikan dengan leverage (X1). Variabel moderasi yang digunakan dalam penelitian ini adalah good corporate governance.

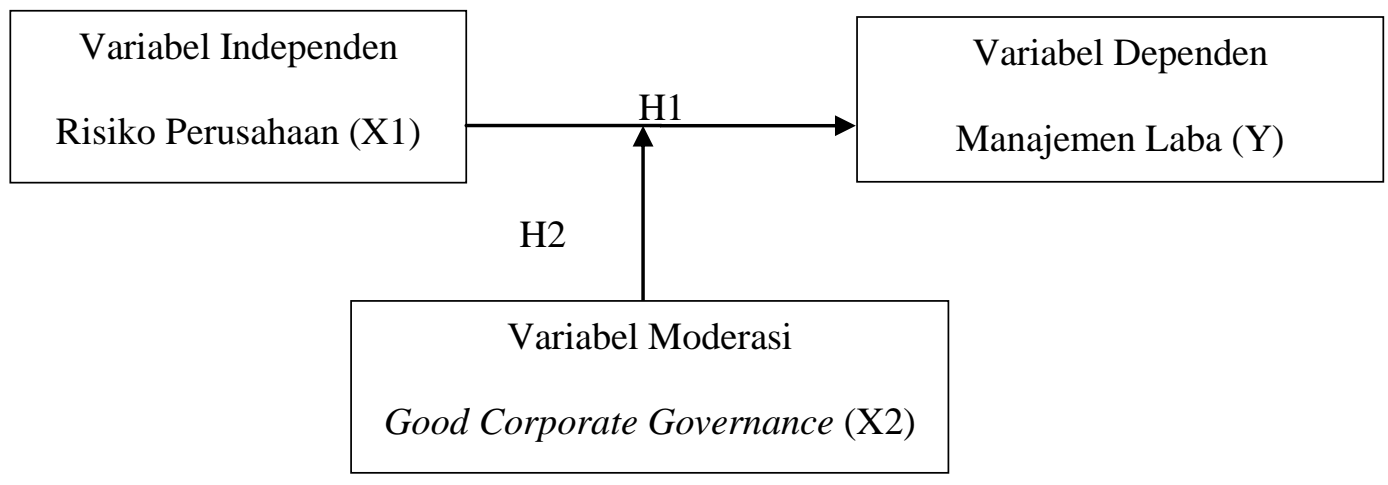

Sumber : Data Diolah, 2017

\section{Gambar 1. Desain Penelitian}

Populasi dalam peneliitian ini meliputi seluruh perusahaan manufaktur yang terdaftar di Bursa Efek Indonesia tahun 2014 - 2016. Peneliti menggunakan perusahaan manufaktur sebagai sampel dikarenakan pertimbangan homogenitas data. Selain itu perusahaan manufaktur juga memiliki skala produksi yang cukup besar sehingga untuk dapat melakukan produksi dalam skala besar tersebut perusahaan membutuhkan pendanaan yang cukup besar Dengan demikian perusahaan juga memiliki peluang untuk melakukan manajemen laba yang 
Ida Ayu Devi Candra Pradnyani dan Ida Bagus Putra Astika. Moderasi...

berhubungan dengan usaha untuk mendapatkan kepercayaan dari kreditur. Sampel yang digunakan dalam penelitian ini adalah seluruh perusahaan manufaktur yang terdaftar di Bursa Efek Indonesia pada tahun 2014-216

Teknik purposive sampling merupakan teknik pengambilan sampel berdasarkan beberapa ketentuan yang diinginkan oleh peneliti (Sugiyono, 2016:120). Pengambilan sampel perusahaan dilakukan berdasarkan kriteria sebagai berikut 1) Perusahaan manufaktur yang secara berturut-turut terdaftar di Bursa Efek Indonesia selama tahun 2014 sampai tahun 2016.Alasan dipilihnya kriteria ini adalah untuk menjaga kekonsistenan data untuk data timeseries. 2) Perusahaan yang menyediakan data laporan keuangan (balance sheet), laporan laba rugi (income statement), laporan arus kas (cash flow), dan seluruh data yang berkaitan dengan penelitian ini. Alasan dipilihnya kriteria ini adalah untuk menemukan data dari variable yang digunakan dalam penelitian. 3) Perusahaan manufaktur yang dalam laporan keuangannya dinyatakan dalam Rupiah. Alasan dipilihnya kriteria ini adalah karena nilai kurs mata uang asing berubah-ubah dan tidak tetap. Pada Tabel 1. menjelaskan jumlah sampel yang digunakan dalam penelitian ini. 
Tabel 1.

Proses dan Hasil Seleksi Sampel berdasarkan Kriteria

\begin{tabular}{|c|c|c|}
\hline No. & Keterangan & Jumlah \\
\hline 1. & $\begin{array}{l}\text { Perusahaan manufaktur yang secara berturut-turut terdaftar } \\
\text { di Bursa Efek Indonesia selama tahun } 2014 \text { sampai tahun } \\
2016 \text {. }\end{array}$ & 123 \\
\hline 2. & $\begin{array}{l}\text { Perusahaan yang tidak menyediakan data laporan keuangan } \\
\text { (balance sheet), laporan laba rugi (income statement), } \\
\text { laporan arus kas (cash flow), dan seluruh data yang berkaitan } \\
\text { dengan penelitian ini }\end{array}$ & (11) \\
\hline 3. & $\begin{array}{l}\text { Perusahaan manufaktur yang dalam laporan keuangannya } \\
\text { tidak dinyatakan dalam Rupiah. }\end{array}$ & (16) \\
\hline 4. & Jumlah populasi yang siap disampling & 96 \\
\hline \multicolumn{2}{|c|}{ Jumlah Sampel Akhir (Slovin) } & 68 \\
\hline \multicolumn{2}{|c|}{ Tahun Pengamatan } & 3 \\
\hline \multicolumn{2}{|c|}{ Jumlah Sampel $=(68$ perusahaan $\times 3$ tahun $)$} & 204 \\
\hline
\end{tabular}

Metode pengumpulan data yang digunakan dalam penelitian ini adalah metode observasi nonparticipant, yaitu observasi yang dilakukan tanpa melibatkan diri dan hanya sebagai pengamat independen (Sugiyono, 2016:156). Data dikumpulkan dengan cara mencatat, mengamati, serta mempelajari bukubuku, karya ilmiah berupa skripsi, jurnal akuntansi, catatan-catatan, dan situs yang relevan, dan berkaitan dengan penelitian yang dilakukan. Teknik analisis data yang digunakan dalam penelitian ini adalah Moderated Regression Analysis (MRA) dengan uji selisih mutlak.Sebelum melakukan MRA perlu dilakukan analisis faktor terlebih dahulu terhadap keempat dimensi GCG, guna memperoleh satu proksi yang bisa mewakili GCG untuk dilakukan analisis selanjutnya. Setelah melakukan analisis faktor, selanjutnya adalah melakukan uji asumsi klasik, karena data harus lolos uji asumsi klasik sebelum melakukan MRA. 
Ida Ayu Devi Candra Pradnyani dan Ida Bagus Putra Astika. Moderasi...

\section{HASIL DAN PEMBAHASAN}

Analisis faktor merupakan analisis yang digunakan untuk mereduksi data sehingga didapatkan satu faktor yang akan mewakili variabel untuk diregresi lebih lanjut. Variabel good corporate governance di proksikan dengan komite audit, komisaris independen, kepemilikan manajerial, dan kepemilikan institusional. Setelah dilakukan analisis faktor variabel moderasi sebagai proksi good corporate governance adalah komite audit (komaud) yang diperoleh dari hasil hitungan pada Tabel 2.berikut.

Tabel 2.

KMO and Bartlett's Test

\begin{tabular}{llr}
\hline Kaiser-Meyer-Olkin Measure of Sampling Adequacy. & $\mathbf{0 , 5 0 7}$ \\
\hline \multirow{2}{*}{ Bartlett's Test of Sphericity } & Approx. Chi-Square & 14,325 \\
& Df & 6 \\
& Sig. & 0,026 \\
\hline Sumber: Data diolah, 2017 & &
\end{tabular}

Berdasarkan nilai Kaiser-Meyer-Olkin (KMO) and Bartlett's Test analisis faktor dapat dilanjutkan karena memberikan nilai $\mathrm{KMO}$ diatas 50\% dan signifikan.

Tabel 3.

Anti-image Matrices

\begin{tabular}{llcccc}
\hline & & Komaud & Komind & Kepinst & Kepman \\
\hline Anti-image Covariance & Komaud & 0,944 & $-0,218$ & 0,037 & 0,014 \\
& Komind & $-0,218$ & 0,941 & $-0,005$ & 0,071 \\
& Kepinst & 0,037 & $-0,005$ & 0,991 & 0,088 \\
& Kepman & 0,014 & 0,071 & 0,088 & 0,986 \\
Anti-image Correlation & Komaud & 0,506 & $-0,231$ & 0,038 & 0,014 \\
& Komind & $-0,231$ & 0,505 & $-0,005$ & 0,073 \\
& Kepinst & 0,038 & $-0,005$ & 0,492 & 0,089 \\
& Kepman & 0,014 & 0,073 & 0,089 & 0,504 \\
\hline
\end{tabular}

Sumber: Data diolah, 2017 
Dari nilai Anti-image Correlationvariabel komite audit (komaud) layak digunakan untuk mewakili dimensi GCG sebagai variabel GCG. Pertimbangan ini juga diperkuat dengan $\%$ of variance dari Initial Eigenvalues yang paling tinggi.

Tabel 4.

Total Variance Explained

\begin{tabular}{|c|c|c|c|c|c|c|c|c|c|}
\hline \multicolumn{4}{|c|}{ Initial Eigenvalues } & \multicolumn{3}{|c|}{$\begin{array}{l}\text { Extraction Sums of } \\
\text { Squared Loadings }\end{array}$} & \multicolumn{3}{|c|}{$\begin{array}{l}\text { Rotation Sums of } \\
\text { Squared Loadings }\end{array}$} \\
\hline $\begin{array}{l}\text { Compone } \\
\text { nt }\end{array}$ & Total & $\begin{array}{c}\% \text { of } \\
\text { Variance }\end{array}$ & $\begin{array}{l}\text { Cumulati } \\
\text { ve } \%\end{array}$ & Total & $\begin{array}{c}\% \text { of } \\
\text { Variance }\end{array}$ & $\begin{array}{l}\text { Cumulati } \\
\text { ve } \%\end{array}$ & Total & $\begin{array}{c}\% \text { of } \\
\text { Variance }\end{array}$ & $\begin{array}{c}\text { Cumul } \\
\text { ative } \\
\%\end{array}$ \\
\hline 1 & 1,255 & 31,387 & 31,387 & 1,255 & 31,387 & 31,387 & 1,247 & 31,183 & 31,18 \\
\hline 2 & 1,087 & 27,167 & 58,555 & 1,087 & 27,167 & 58,555 & 1,095 & 27,371 & $\begin{array}{r}58,55 \\
5\end{array}$ \\
\hline 3 & 0,897 & 22,416 & 80,971 & & & & & & \\
\hline 4 & 0,761 & 19,029 & 100,000 & & & & & & \\
\hline
\end{tabular}

Berdasarkan Tabel 5. dapat dijelaskan mengenai statistik deskriptif data yang digunakan pada penelitian ini, yakni Manajemen Laba (DA) adalah suatu kondisi dimana manajemen melakukan intervensi dalam proses penyusunan laporan keuangan eksternal (meratakan, menaikkan, dan menurunkan laba). DA memiliki nilai rata-rata sebesar 0,0287 dengan standar deviasi sebesar 0,13578 maka dapat disimpulkan bahwa terjadi penyimpangan terhadap nilai rata-ratanya. Nilai standar deviasi yang lebih besar dari nilai rata-rata menunjukkan adanya jarak yang sangat jauh antara nilai minimum $(-0,33)$ dengan nilai maksimum $(0,59)$ pada variabel manajemen laba. Nilai rata-rata DA bernilai positif 0,0287 hal ini mengidentifikasikan perusahaan melakukan pola manajemen laba dengan menaikkan laba dalam jangka panjang. Jadi dapat dinyatakan bahwa terdapat manajemen laba dalam kaitannya dengan resiko perusahaan. Sampel perusahaan yang terdaftar di BEI dengan manajemen laba minimum yaitu $-0,33$ adalah PT 
Ida Ayu Devi Candra Pradnyani dan Ida Bagus Putra Astika. Moderasi...

Lion Metal Works Tbk pada tahun 2014 dan manajemen laba maksimal yaitu 0,59 adalah PT Indal Alumunium Industry Tbk pada tahun 2015.

Tabel 5. Statistik Deskriptif

\begin{tabular}{lccccc}
\hline & N & Minimum & Maximum & Mean & $\begin{array}{c}\text { Std. } \\
\text { Deviation }\end{array}$ \\
\hline Da & 204 & $-0,33$ & 0,59 & 0,0287 & 0,13578 \\
Lev & 204 & 0,07 & 0,89 & 0,4488 & 0,20674 \\
ln_komaud & 204 & 0,69 & 1,61 & 1,1062 & 0,14202 \\
$\begin{array}{l}\text { Lev- } \\
\text { lnkomaud }\end{array}$ & 204 & 0,06 & 1,19 & 0,6598 & 0,24462 \\
$\begin{array}{l}\text { Valid N } \\
\text { (listwise) }\end{array}$ & 204 & & & & \\
\hline Sumber: Data diolah, 2017 & & & & & \\
\end{tabular}

Risiko perusahaan pada penelitian ini diproksikan dengan leverage. Leverage (LEV) adalah suatu perbandingan yang mencerminkan besarnya hutang yang digunakan untuk pembiayaan oleh perusahaan dalam menjalankan aktivitas operasinya. Nilai rata-rata leverage adalah 0,4488 . Nilai standar deviasi 0,20674 yang lebih rendah dibandingkan nilai rata-rata. Nilai minimum leverage sebesar 0,07 dan nilai maksmimum sebesar 0,89 . Sampel perusahaan yang terdaftar di BEI denganleverage paling kecil adalah 0,07 pada PT Sucaco Tbk tahun 2014 dan yang paling besar 0,89 pada PT Multi Prima Sejahtera Tbk tahun 2016.

GCG adalah proses untuk meningkatkan keberhasilan usaha dan akuntabilitas perusahaan guna perusahaan guna mewujudkan nilai Pemilik Modal/RPB dalam jangka panjang dengan tetap memperhatikan kepentingan stakeholder dan shareholdernya. Pada penelitian proksi yang mewakili GCG sesuai dengan analisis faktor yaitu Komite Audit (Komaud). Nilai rata-rata komite 
audit sebesar 1,1062. Nilai standar deviasi 0,14202 yang lebih rendah dibandingkan dengan nilai rata-rata. Nilai minimum komite audit sebesar 0,69 dan nilai maksimum sebesar 1,61. Sampel perusahaan yang terdaftar di BEI dengan komite audit paling kecil adalah 0,69 pada PT Inal Alumunium Industry Tbk tahun 2015 dan 2016; PT Lion Metal Works Tbk tahun 2015 dan 2016; PT Lionmesh Prima Tbk tahun 2015 dan 2016; PT Sekar Bumi Tbk tahun 2014, 2015, dan 2016; serta PT Sekar Laut Tbk 2015 dan 2016. Sampel perusahaan dengan komite audit paling besar adalah 1,61 pada PT Malindo Feedmill Tbk tahun 2015 dan 2016, serta PT Charoen Pokphand Indonesia Tbk tahun 2015 dan 2016.

Selisih Leverage dan Komite Audit memiliki rata-rata sebesar 0,6598. Nilai standar deviasi 0,24462 yang lebih rendah dibandingkan nilai rata-rata. Nilai minimum interaksi leverage dan komite audit sebesar 0,06 dan nilai maksimum interaksi leverage dan komite audit sebesar 1,19. Sampel perusahaan yang terdaftar di BEI dengan moderasi leverage dan komite audit paling kecil adalah 0,06 pada PT Sekar Bumi Tbk tahun 2016 dan yang paling besar adalah 1,19 pada PT Charoen Pokphand Indonesia Tbk tahun 2016.

Uji asumsi klasik dilakukan sebelum melakukan uji MRA. Pengujian ini dilakukan untuk menghindari adanya informasi yang bias yang dihasilkan dari sampel peneliti. 
Tabel 6.

Hasil Uji Asumsi Klasik

\begin{tabular}{lll}
\hline Uji Asumsi Klasik & Hasil Uji & Keterangan \\
\hline Uji Normalitas & $\begin{array}{l}\text { Data tersebar merata disekitar } \\
\text { garis diagonal }\end{array}$ & Berdistribusi normal \\
Uji Autokorelasi & $1,77852<2,165<2,22148)$ & Bebas dari autokorelasi \\
Uji Multikolinearitas & $\begin{array}{l}\text { Tolerance }(0,012) ;(0,027) ; \\
(0,009)<0,1\end{array}$ & \\
& VIF $(80,834) ;(36,506) ;$ & Terjadi multikolinearitas \\
& $(116,510)>10$ & \\
Uji Heteroskedastisitas & $\mathrm{p}(0,466) ;(0,576) ;(0,747)$ & $\begin{array}{l}\text { Tidak terjadi } \\
\text { heteroskedastisitas }\end{array}$ \\
& &
\end{tabular}

Sumber: Data diolah, 2017

Pengujian dengan menggunakan Moderated Regression Analysis (MRA) dilakukan untuk mendapatkan bukti empiris apakah suatu variabel merupakan variabel pemoderasi yakni dengan menggunakan uji selisih mutak. Persamaan Moderated Regression Analysis (MRA) pada penelitian ini adalah sebagai berikut:

$$
\begin{array}{r}
\mathrm{Y} 1=\alpha+\beta_{1} \mathrm{X}_{1}+\varepsilon \ldots \ldots \ldots \ldots \ldots \ldots \ldots \ldots \ldots \ldots \ldots \ldots \\
\mathrm{Y} 2=\alpha+\beta_{1} \mathrm{X}_{1}+\beta_{2} \mathrm{X}_{2}+\beta_{3}\left|\mathrm{X}_{1}-\mathrm{X}_{2}\right|+\varepsilon
\end{array}
$$

Hasil dari pengujian regresi pada penelitian ini disajikan dalam 2 (dua) tahap yaitu uji hipotesis 1 (H1) dengan regresi sederhana dan uji hipotesis $2(\mathrm{H} 2)$ dengan MRA. Uji hipotesis 1 bertujuan memberi dukungan atau memperkuat dukungan pada riset sebelumnya khususnya hipotesis debt covenant hyphotesis (Watt and Zimmerman, 1986). Sedangkan uji hipotesis 2 bertujuan untuk mendapatkan bukti empiris kemampuan GCG di perusahaan. Hasil regresi disajikan pada Tabel 7. dan Tabel 8. berikut: 
Tabel 7.

Hasil Uji Regresi Sederhana

\begin{tabular}{|c|c|c|c|c|c|}
\hline \multirow[t]{2}{*}{ Model } & \multicolumn{2}{|c|}{$\begin{array}{c}\text { Unstandardized } \\
\text { Coefficients }\end{array}$} & \multirow{2}{*}{$\begin{array}{c}\text { Standardized } \\
\text { Coefficients } \\
\text { Beta }\end{array}$} & \multirow[t]{2}{*}{$\mathbf{t}$} & \multirow[t]{2}{*}{ Sig. } \\
\hline & B & Std.Error & & & \\
\hline 1 (Constant) & $-0,013$ & 0,023 & & -0.580 & 0,563 \\
\hline Lev & 0,093 & 0,046 & 0,142 & 2,035 & 0,043 \\
\hline $\mathrm{F}-$ & & & 4.140 & & \\
\hline Sig F & & & 0,043 & & \\
\hline R Square & & & 0,020 & & \\
\hline Adjusted R Square & & & 0,015 & & \\
\hline
\end{tabular}

Pada tabel 7.dantabel 8. dapat dilihat nilai koefisien regresi dari variabel leverage, dan manajemen laba (konstansta), sehingga secara sistematis diperoleh persamaan sebagai berikut :

$$
\begin{aligned}
& \mathrm{Y} 1=-0,013 \alpha+0,093 \mathrm{X} 1+\varepsilon \ldots \ldots \ldots \ldots \ldots \ldots \ldots \ldots \ldots \ldots \ldots \\
& \mathrm{Y} 2=0,123 \alpha+1,337 \mathrm{X} 1-1,385 \mathrm{X} 2+1,270|\mathrm{X} 1-\mathrm{X} 2|+\varepsilon
\end{aligned}
$$

Tabel 8.

Hasil Uji MRA

\begin{tabular}{lccccc}
\hline \multicolumn{1}{c}{ Model } & \multicolumn{2}{c}{$\begin{array}{c}\text { Unstandardized } \\
\text { Coefficients } \\
\text { S }\end{array}$} & $\begin{array}{c}\text { Standardized } \\
\text { Coefficients } \\
\text { Beta }\end{array}$ & t Eror & Sig. \\
\hline 1 (Constant) & 0,123 & 0,077 & & 1,605 & 0,110 \\
Lev & 1,337 & 0,396 & 2,036 & 3,375 & 0,001 \\
LnKomaud & $-1,385$ & 0,388 & $-1,449$ & $-3,574$ & 0,000 \\
Lev-Komaud & 1,270 & 0,402 & 2,286 & 3,160 & 0,002 \\
F & & & 7,370 & & \\
Sig F & & 0,000 & & \\
R Square & & 0,100 & & \\
Adjusted $R$ Square & & 0,086 & & \\
\hline
\end{tabular}

Sumber: Data diolah, 2017

Berdasarkan Tabel 7.diperoleh besarnya nilai Adjusted R square sebesar 0,015 yang berarti 1,5 persen variabel manajemen laba dijelaskan oleh variabel leverage sedangkan sisanya lagi $98.5 \%$ dijelaskan oleh variabel lain yang tidak dijelaskan dalam model. Berdasarkan Tabel 4.10diperoleh besarnya nilai Adjusted $\mathrm{R}$ square sebesar 0,086 yang berarti 8.6 persen variabel manajemen laba dijelaskan oleh variabel leverage, GCG danmoderasi selisih mutlak. Sedangkan 
Ida Ayu Devi Candra Pradnyani dan Ida Bagus Putra Astika. Moderasi...

sisanya sebesar 91,4 persen dijelaskan oleh variabel lain yang tidak dimasukkan dalam model penelitian.

Uji $F$ menghasilkan $F_{\text {hitung }}$ sebesar 2,035 dengan signifikansi 0,043 untuk uji hipotesis $1(\mathrm{H} 1)$ dan nilai $F_{\text {hitung }}$ sebesar 7,370 dengan signifikansi sebesar 0,000 keduanya lebih kecil dari $\alpha=0,05$ ( $\alpha=5$ persen), yang berarti bahwa model yang digunakan dalam penelitian ini telah layak (fit). Dengan demikian model penelitian yang digunakan layak dan pembuktian hipotesis dapat dilanjutkan.

Berdasarkan hasil uji regresi diatas, dapat diketahui bahwa nilai konstanta -0,013 memiliki arti apabila Leverage sama dengan nol, maka Manajemen Laba sebesar positif $-0,013$.

Nilai koefisien regresi Leverage (LEV) sebesar 0,093 memiliki arti apabila Leverage naik sebesar satu satuan, maka Manajemen Laba meningkat sebesar 0,093 .

Nilai koefisien regresi Komite Audit (Komaud) sebesar -1,385 memiliki arti apabila komite audit naik sebesar satu satuan, maka Manajemen Laba menurunsebesar 1,385 satuan dengan asumsi variabel lainnya konstan.

Nilai koefisien moderasi Lev-Komaud sebesar 1,270 mengindikasikan bahwa moderasi (lev-komite audit) memperkuat Manajemen Laba yang meningkatkan laba. Kondisi ini ditunjukkan oleh koefisien beta moderasi 1,270 $>0,093$.

Adapun hasil dari pengujian kesesuaian model dalam penelitian ini telah

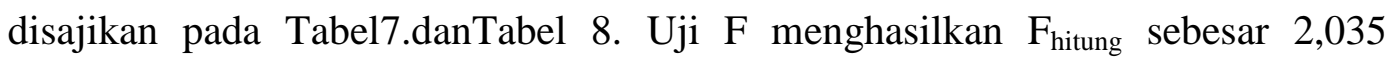


dengan signifikansi 0,043 untuk uji hipotesis 1 (H1) dan nilai $F_{\text {hitung }}$ sebesar 7,370 dengan signifikansi sebesar 0,000 keduanya lebih kecil dari $\alpha=0,05$ ( $\alpha=5$ persen), yang berarti bahwa model yang digunakan dalam penelitian ini telah layak (fit). Dengan demikian model penelitian yang digunakan layak dan pembuktian hipotesis dapat dilanjutkan.

Pada penelitian ini koefisien determinasi dilihat melalui nilai adjusted $R^{2}$. Adapun nilai dari Adjusted $R^{2}$ pada penelitian ini telah disajikan pada Tabel 4.9. Berdasarkan pada Tabel 7. dapat dilihat bahwa nilai dari Adjusted $R^{2}$ pada persamaan pertama sebesar 0,015 dimana memiliki arti bahwa 1,5\% variasi perubahan manajemen laba dapat dijelaskan oleh variabel leverage. Sisanya sebesar 98,5\% dipengaruhi oleh variabel lain diluar dari model yang digunakan dalam persamaan.

Pada Tabel 8. dapat dilihat bahwa nilai dari adjusted $R^{2}$ pada persamaan kedua sebesar 0,086 dimana memiliki arti bahwa 8,6\% variasi perubahan Manajemen Laba dapat dijelaskan oleh variable Leverage, Komite Audit. Sisanya sebesar 91,4\% dipengaruhi oleh variabel lain diluar dari model yang digunakan dalam persamaan kedua. Hasil analisis koefisien determinasi dari kedua persamaan pada penelitian ini, dapat diketahui bahwa terjadi peningkatan persentase variasi perubahan Manajemen Laba yang dapat dijelaskan oleh model dari persamaan pertama sebesar $1,5 \%$ menjadi $8,6 \%$ pada persamaan kedua. Hal ini menunjukkan bahwa dengan adanya moderasi menyebabkan peningkatan persentase variasi perubahan Manajemen Laba yang dapat dijelaskan oleh variabel bebas dan variabel moderasi dari model yang digunakan dalam penelitian ini. 
Ida Ayu Devi Candra Pradnyani dan Ida Bagus Putra Astika. Moderasi...

Uji statistik $\mathrm{t}$ dilakukan untuk mengetahui seberapa jauh pengaruh satu variabel independen secara individual menerangkan variasi variabel dependen. Uji statistik $\mathrm{t}$ dilakukan dengan membandingkan hasil nilai signifikansi dengan $\alpha=$ 0,05 dan dapat dijelaskan bahwa berdasarkan Tabel 7. diperoleh nilai signifikansi uji t dari variabel leveragedengan nilai $p$-value sebesar 0,043 lebih kecil dari $\alpha=$ 0,05 serta nilai koefisien regresi sebesar 0,093. Hal ini mengindikasikan bahwa leverage berpengaruh positif dan signifikan pada manajemen laba, sehingga hipotesis pertama dalam penelitian ini diterima.Semakin tinggi tingkat leverage perusahaan maka manajemen laba yang dilakukan oleh manajemen juga akan meningkat. Ketika perusahaan berada pada tingkat leverage yang tinggi, berarti perusahaan dapat dikatakan berada dalam keaadaan insovable, artinya perusahaan berada pada keadaan dimana kekayaan yang dimiliki lebih kecil dibanding hutangnya. Dengan kata lain sebagian besar sumber pendanaan perusahaan berasal dari hutang.Hasil yang dicapai sesuai dengan hipotesis dalam perjanjian utang (debt covenant hyphotesis) yang menyatakan bahwa manajer termotivasi melakukan manajemen laba untuk menghindari pelanggaran perjanjian hutang (Santoso dan Prasetyo,2012).

Berdasarkan Tabel 7. diperoleh nilai signifikansi uji t dari variabel moderasi (LEV-KOMAUD) pada manajemen laba dengan nilai $p$-value sebesar 0,002 lebih kecil dari $\alpha=0,05$ serta nilai koefisien regresi sebesar 1,270 . Hal ini menunjukkan bahwa GCG mampu memperkuat pengaruh leverage pada Manajemen Laba, sehingga hipotesis kedua dalam penelitian ini diterima. Semakin tinggi tingkat leverage suatu perusahaan maka manajemen laba itu 
sendiri juga akan tinggi, lalu munculnya GCG dengan proksi komite audit memunculkan kecenderungan suatu perusahaan akan melakukan manipulasi laba dengan sangat hati-hati sehingga tidak terlihat kecenderungannya, hal tersebut karena perusahaan ingin menjaga kepercayaan pihak eksternal yaitu investor, masyarakat, dan kreditur terhadap keadaan perusahaan itu sendiri. Hasil penelitian ini konsisten dengan hasil penelitian yang dilakukan oleh Nasution dan Setiawan (2007), Herawaty (2008), Jao dan Pagulung (2011) serta Sari dan Astika (2015) yang menyatakan bahwa GCG mampu memoderasi pengaruh leverage pada manajemen laba. Tetapi kondisi yang berbeda terjadi pada sebuah penelitian yang pernah di lakukan oleh Ningsaptiti (2010), Putri (2012), serta Butar dan Sudarsi (2012) yang menyatakan bahwa GCG tidak berpengaruh pada manajemen laba.

Hasil penelitian memberikan tambahan informasi mengenai bagaimana kemampuan GCG memoderasi pengaruh risiko perusahaan (leverage) pada manajemen laba. Terdapat bukti empiris yang diperoleh melalui penelitian ini terkait hasil olah data statistik di perusahaan manufaktur periode 2014-2016 yang menunjukkan risiko perusahaan (leverage) berpengaruh positif pada manajemen laba, dan GCG berpengaruh pada manajemen laba.

Kemampuan GCG sebagai variabel moderasi menunjukkan bahwa pendekatan keagenan yang digunakan pada penelitian ini dapat diaplikasikan sesuai teori. Variabel GCG dapat teridentifikasi sebagai variabel moderasi yang dapat memberikan pengaruh terhadap penelitian ini yakni pengaruh risiko perusahaan (leverage)pada manajemen laba. Teori keagenan menjelaskan hubungan antar agen dan prinsipal yang memunculkan asimetri informasi 
Ida Ayu Devi Candra Pradnyani dan Ida Bagus Putra Astika. Moderasi...

sehingga dapat menimbulkan adanya konflik.Konflik kepentingan antara prinsipal dan agen dapat diminimalkan dengan cara melakukan mekanisme pengawasan yang dapat membatasi kesempatan agen untuk melakukan perilaku oportunistik.

Hasil penelitian ini dapat menjadi bahan pertimbangan bagi kreditur dalam memilih kelayakan pertanggungjawaban perusahaan dalam kaitannya dengan kredit yang dikucurkan.

\section{SIMPULAN}

Berdasarkan hasil pengujian dan analisis yang diperoleh dalam penelitian ini, maka dapat disimpulkan bahwa risiko perusahaan (leverage) berpengaruh positif pada manajemen laba di perusahaan manufaktur yang terdaftar di BEI tahun 20142016. Hal ini berarti semakin tinggi tingkat leverage perusahaan maka manajemen laba yang dilakukan oleh manajemen juga akan meningkat.

GCG memperkuat pengaruh risiko perusahaan (leverage) pada manajemen laba di perusahaan manufaktur yang terdaftar di BEI tahun 2014-2016. Hal ini berarti semakin tinggi tingkat leverage suatu perusahaan maka manajemen laba itu sendiri juga akan tinggi, lalu munculnya GCG dengan proksi komite audit mampu mendorong manajemen untuk melakukan manajemen laba karena perusahaan ingin menjaga kepercayaan pihak eksternal yaitu investor, masyarakat, dan kreditur terhadap keadaan perusahaan itu sendiri.

Berdasarkan hasil penelitian dan simpulan di atas, maka saran yang dapat diberikan adalah menambahkan variabel moderasi lainnya yang dapat mempengaruhi manajemen laba mengingat Adjusted $\mathrm{R}^{2}$ baru $8,6 \%$ dan penelitian 
selanjutnya disarankan untuk menggunakan metode perhitungan GCG yang lain dan untuk menilai kondisi leverage pada perusahaan.

\section{REFERENSI}

Astika, Ida Bagus Putra. 2011. Konsep - Konsep Dasar Akuntansi Keuangan. Udayana University Press.

Ball, R., and P. Brown. 1968. An Empirical Evaluation of Accounting Income Numbers. Journal of Accounting Research, pp. 159-178.

Carlson, S. J., dan Chenchuramaiah, T. B. (1997).Ownership Differences and Firms Income Smoothing Behavior. Journal of Business Finance \& Accounting, 24 (2), pp. $179-191$.

Chung, R., Firth, M., Kim, J.B. 2002. Institutional Monitoring and Opportunistic Earnings Management. Journal of Corporate Finance,pp. 29-48.

Dechow, P. M., Sloan, R.G., dan Sweeney, A.P. 1995. Detecting Earnings Management. The Accounting Review, 70: 193-225.

Dewantari, Ni Putu Santi dan Badera I Dewa Nyoman. 2015. Good Corporate Governance, Ukuran Perusahaan, Dan Financial Leverage Sebagai Prediktor Perataan Laba. Jurnal Akuntansi Universitas Udayana.

Eckel, Norm. 1981. The Income Smooting Research Hypothesis Revisited. Journal ABACUS. pp: $28-40$.

Effendi, Muh. Arief. 2009. The Power of Good Corporate Governance Teori dan Implementasi. Jakarta: Salemba Empat.

Ghozali, Imam. 2016. Aplikasi Analisis Multivariate dengan Program IBM SPSS23. Semarang:Badan Penerbit Universitas Diponogoro.

Gumanti, dan Singgih.2006. Earning Management antar Industri dan FaktorFaktor Pembatasnya pada Perusahaan Publik di Bursa Efeek Indonesia. Jurnal Akuntansi dan Bisnis, Vol.6 No.2. Hal 181-192.

Hair, Joseph F., Black, William C., and Babin, Barry J. 2006. Multivariate Data Analysis Pearson International Sixth Edition.Bandung:Raja Grafindo Persada. 
Ida Ayu Devi Candra Pradnyani dan Ida Bagus Putra Astika. Moderasi...

Healy, Paul M. 1985. The Effect of Bonus Schemes on Accounting Decisions. Journal of Accounting and Economics, pp. 85-107

Healy, P. and Wahlen J. 1999. A Review of The Earnings Manajement Literature and Its Implications for Standard Setting. Accounting Horizon, 12(4).

Jensen, M.C, and W.H. Meckling. 1976. Theory of the Firm: Managerial Behavior, Agency Cost and Ownership Structure. Journal of Financial Economics, V. 3, No. 4.

Jao, Robert dan Gagaring Pagalung. 2011. Corporate Governance, Ukuran Perusahaan dan Leverage Terhadap Manajemen Laba Perusahaan Manufaktur Indonesia. Jurnal Akuntansi dan Auditing, Vol.8 No.1 1-94.

Juniarta, I Wayan Agus dan Sujana, I Ketut. 2015. Pengaruh Financial Leverage Pada Income Smoothing Dengan Good Corporate Governance Sebagai Variabel Pemoderasi. Jurnal Akuntansi Universitas Udayana, hal. 921939.

Kothari, S.P., Leone, A.J., and Wasley, C.E. 2005. Performance Matched Discretionary Accrual Measures. Journal of Accounting and Economics, 39, pp:163-197.

Kieso, E. Donald, Weygandt, Jerry.J, Warfield, D.Terry. 2001. Akuntansi Intermediate Edisi Sepuluh. Jakarta: Erlangga.

Klein, April. 2002. Audit Committee, Board Of Director Characteristics and Earnings Management. Journal of Accounting and Economics, Vol.33.No.3. August, hal. 375-400.

Lestari, Sri Dewi dan Ni Gusti Putu Wirawati. 2016. Good Corporate Governance Sebagai Pemoderasi Pengaruh Asimetri Informasi Pada Manajemen Laba. E-Journal Akuntansi Universitas Udayana.

Machfoedz, Mas'ud. Financial Ratio Analysis and The Prediction of Earnings Changes in Indonesia. Yogyakarta: Gajahmada University Business Review, No.7/III.1994.

Mahawyahrti, Putu Tiya dan I Gusti Ayu Nyoman Budiasih. 2016. Asimetri Informasi, Leverage, dan Ukuran Perusahaan Pada Manajemen Laba. Jurnal Ilmiah Akuntansi dan Bisnis, Vol. 11. No.2.

Marpaung, c.o., \& Latrini, Y. 2014. Pengaruh Dewan Komisaris Independen, Komite Audit, Kualitas Audit, Dan Kepemilikan Manajerial Pada Perataan Laba. E-Jurnal Akuntansi Universitas Udayana, 7(2), hal. 279289. 
McMullen, D. 1996. Audit Committee Performance: An Investigation of the Consequences Associated with Audit Committees. Auditing: A Journal of Practice and Theory, pp. 87-103.

Midiastuty, Pratama Puspa dan Mas'ud Machfoedz. 2003. Analisis Hubungan Mekanisme Corporate Governance dan Indikasi Manajemen Laba. Simposium Nasional Akuntansi VI.

Nasution, M., dan Doddy Setiawan. 2007. "Pengaruh Corporate Governance Terhadap Manajemen Laba di Industri Perbankan Indonesia. Simposium Nasional Akuntansi.

Ningsaptiti, Restie. 2010. Analisis Pengaruh Ukuran Perusahaan dan Mekanisme Corporate Governance Terhadap Manajemen Laba. Semarang: Fakultas Ekonomi Universitas Diponogoro

Novianus. 2016. Hubungan Antara Ukuran Perusahaan, Leverage, Profitabilitas Dengan Manajemen Laba. Yogyakarta:Universitas Sanata Dharma.

Othman, B.H and Zhegal,D. 2006. A Study of Earnings Management Motives in the Anglo-American and Euro-Continental Accounting Models: the Canadian and French Cases. The International Journal of Accoounting, 41, 406-435.

Puspita Sari, Putri dan Ida Bagus Putra Astika. 2015. Moderasi Good Corporate Governance pada Pengaruh Antara Leverage daan Manajemen Laba. EJournal Akuntansi Universitas Udayana. 